\title{
SURVIVAL OF FECAL COLIFORMS AND FECAL STREPTOCOCCI IN STORM DRAIN SEDIMENT
}

\author{
Robert P. Marino and John J. Gannon* \\ Department of Environmental and Industrial Health, School of Public Health, \\ The University of Michigan, Ann Arbor, MI 48109, U.S.A.
}

(First received May 1990; accepted in revised form March 1991)

\begin{abstract}
This study defined major factors influencing the survival of the bacterial indicators, fecal coliforms (FC) and fecal streptococci (FS), in separate storm drain sediments during dry weather periods. FC and FS abilities to survive were determined by field sampling and experimental treatments of laboratory stream models. The effects of interspecific competition, antagonism, and predation on FC and FS survivals were determined using recirculating models that contained either untreated drain water and sediment, cycloheximide-treated drain sediment, or autoclaved drain water and sediment seeded with drain isolates of FC and FS. Storm drain sediment FC and FS counts were stable at $10^{5} / 100 \mathrm{ml}$ during dry weather (4-6 days), with little or no bacterial supplementation from the water $\left(10^{1}-10^{2} / 100 \mathrm{ml}\right)$. Untreated (control) model FC and FS populations stabilized at $10^{3} / 100 \mathrm{ml}$ for 7-9 days. In cycloheximide-treated models, FS and FC survived at $10^{4}$ and $10^{5} / 100 \mathrm{ml}$, respectively. In autoclaved-seeded models, FS and FC initial counts of $10^{4} / 100 \mathrm{ml}$ increased to and stabilized at $10^{7}-10^{9} / 100 \mathrm{ml}$. Separate storm drain sediments serve as reservoirs of high concentrations of FC and FS during warm, dry weather periods. FC exhibited some ability to multiply in drain sediment. Native microfloral competition/antagonism (including bacterial predation) and protozoan predation are major biotic factors influencing FC and FS survivals. During warm, dry weather periods, abiotic factors were generally stable and had minimal affects on FC and FS survivals.
\end{abstract}

Key words -indicator bacteria, sediments, urban storm drains, survival, competition, antagonism, predation

\section{INTRODUCTION}

Major factors influencing the survival of the bacterial pollution indicators, fecal coliforms (FC) and fecal streptococci (FS), in storm drain sediment during dry weather periods were defined in this study. Field sampling and experimental treatments of laboratory stream models were used to determine FC and FS abilities to survive and multiply in drain sediments. Recirculating models that contained either untreated drain water and sediment, cycloheximide-treated drain sediment, or autoclaved drain water and sediments seeded with drain isolates of FC and FS were used to determine the effects of interspecific competition, antagonism, and predation on bacterial survival.

FC, salmonellae, and E. coli survival in freshwater sediments has been demonstrated by Hendricks (1971), Van Donsel and Geldreich (1971), Grimes (1975), LaLiberti and Grimes (1982), and Struck (1988). Survival of $E$. coli, TC, FC, FS, salmonellae, and Vibrio cholerae in estuarine sediments has been shown by Sayler et al. (1975), Goyal et al. (1977, 1979), Erkenbrecher (1981), and Hood and Ness (1982). E. coli, TC, FC, FS, and amoebae have been demonstrated to survive in marine sediments by

*Author to whom all correspondence should be addressed.
Savage (1905), Rittenberg et al. (1958), Bonde (1967), Gerba and McLeod (1976), and O'Malley et al. (1982). Indeed, bacterial concentrations were found to be much higher in sediments than in the overlying waters (Hendricks, 1971; Van Donsel and Geldreich, 1971; Goyal et al. 1977, 1979; Erkenbrecher, 1981; LaLiberti and Grimes, 1982). This is probably due, in part, to the settling of bacteria adsorbed to temporarily suspended sediments (Schillinger, 1982; Weiss, 1951). Gerba and McLeod (1976) observed that $E$. coli survival increased rapidly when either autoclaved or fresh estuarine sediments were added to estuarine waters. Hood and Ness (1982) found that E. coli could survive better in non-sterile (fresh) estuarine sediments than in estuarine waters (whether sterile or non-sterile). Burton et al. (1987), using continuousflow chambers containing lake or river sediments, artificially constituted water, and streptomycin-resistant bacteria, found extended bacterial survival in sediments compared to survival in water.

The survival of high concentrations of these bacteria in the sediments is beginning to be recognized as a possible health hazard (Bonde, 1967; Burton et al., 1987; Gary and Adams, 1985; Goyal et al., 1977, 1979; Gerba and McLeod, 1976; Hendricks, 1971; LaLiberti and Grimes, 1982; McDonald et al., 1982; O'Malley et al., 1982; Rittenberg et al., 1958; Savage, 1905; Van Donsel and Geldreich, 1971; Varness et al., 
1978). Grimes (1975), Matson et al. (1978), and Erkenbrecher (1981) caution about activities (e.g. recreational) and natural (storm) events which would resuspend sediments and their bacterial loads, particularly in recreational waters, thus increasing the health risks in such waters.

Separate urban storm drains are known to contribute major bacterial pollution loads to receiving bodies of water (Benzie and Courchaine, 1966; Burm and Vaughan, 1966; DEIH, 1986; Geldreich et al., 1968; Qureshi and Dutka, 1979; Weibel et al., 1964). However, the source or sources of this pollution are poorly defined. The possibility that drain sediments may serve as reservoirs of fecal bacteria has not been investigated

\section{MATERIALS AND METHODS}

Traver Creek drain was chosen as the proposed study site within the City of Ann Arbor, Mich. (Figs I and 2). Located in the nothern portion of the city, it drains approx. 4566 acres which includes parts of Ann Arbor and Northfield Townships and northern sectors of the city, and empties into the Huron River about 0.8 mile downstream of Argo Dam. About $67 \%$ of the drainage basin lies outside of the city with the remaining area being $31 \%$ residential and $2 \%$ commercial (ENCOTEC, 1982; WCDB and SEMCOG, 1981). In the last 10 years, the Traver Creek basin has undergone much development and, as such, typifies a storm drain servicing a rapidly developing urban area. Other considerations supporting its selection included accessibility to sampling, proximity to laboratory facilities, the availabilty of historical data, and the acquisition of preliminary data from the creek (DEIH, 1986). Traver Creek is a permanently-flowing stream.

Creek survival of indicator bacteria was determined by sampling creek sediments at the mouth of the drain during dry weather (i.e. interstorm periods). The mouth (outlet) was chosen as the primary sampling site because the creek bed slope within the city makes it the site of greatest sedimentation. Dry weather sample runs were carried out with sediment samples being obtained once per day, at the same time of day, for 5-7 days per run. Water samples were collected concurrently in order to monitor dry weather fecal bacterial loadings. These samples were also analyzed for dissolved oxygen (DO), conductivity, $\mathrm{pH}$, and temperature. Sampling occurred from April through December.

A physical model was developed to simulate dry weather drain conditions (Fig. 3). It consists of a recirculating microcosm containing water, rocks, gravel, and sediments obtained from the outlet of the creek. The model was run and sampled for water and sediment indicator bacterial counts in parallel with the dry weather field study, to determine the bacterial survivals in the model and their comparability to field survivals. Replicate model studies were performed and samples collected as per the field study for analysis of fecal bacteria, and for $\mathrm{DO}$, conductivity, $\mathrm{pH}$, and temperature. For the dry weather simulations, the model temperatures were kept at field temperatures $\left(22-25^{\circ} \mathrm{C}\right)$. Preliminary studies indicated that it was essentially impossible to simulate the quality and intensity of sunlight indoors. Thus, fluorescent lighting was used $(900$ lumens, the intensity of very low outdoor lighting) and the photoperiod was as under field conditions (10-12 h/day).

Fecal bacterial multiplication and the effects of interspecific competition and predation on the survival of these bacteria were determined in seeded model studies. The models contained autoclaved $\left(45 \mathrm{~min}\right.$ at $121^{\circ} \mathrm{C}, 15 \mathrm{lb}$ pressure) rocks, gravel, sediment, and water from the creek outlet into which was seeded, once, known quantities and combinations of indicator (fecal) bacteria previously iso-

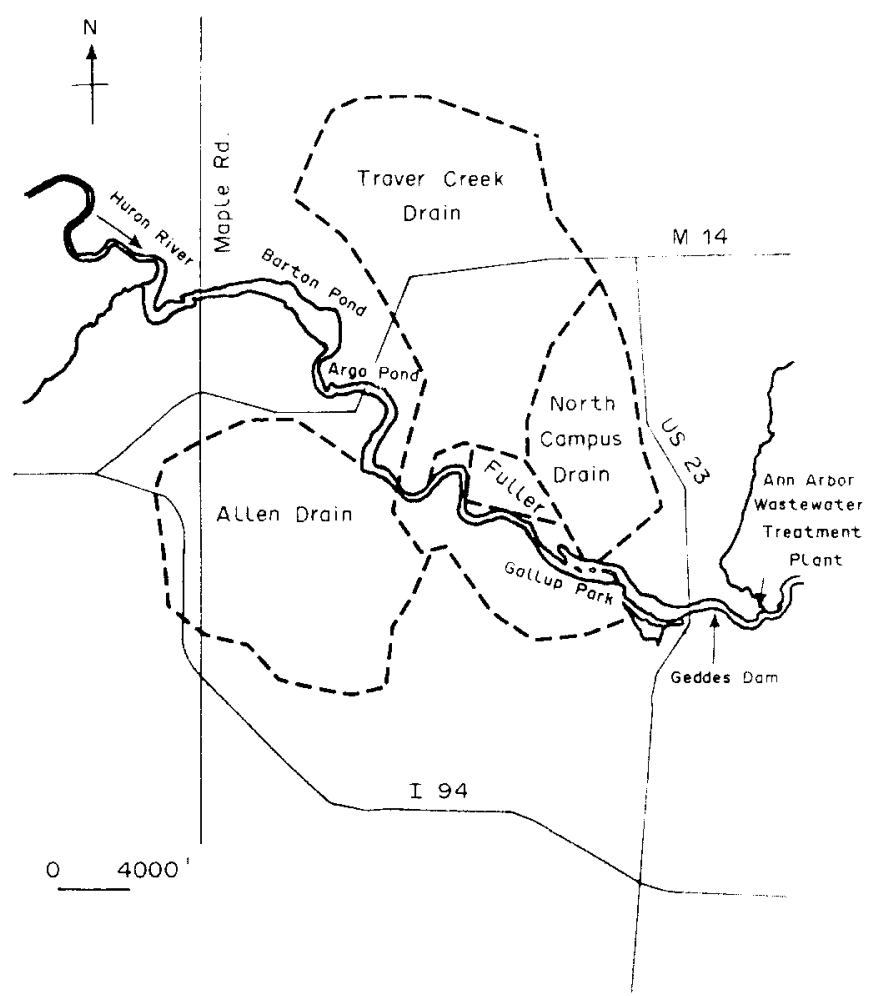

Fig. 1. Drainage areas of major Ann Arbor storm drains. 


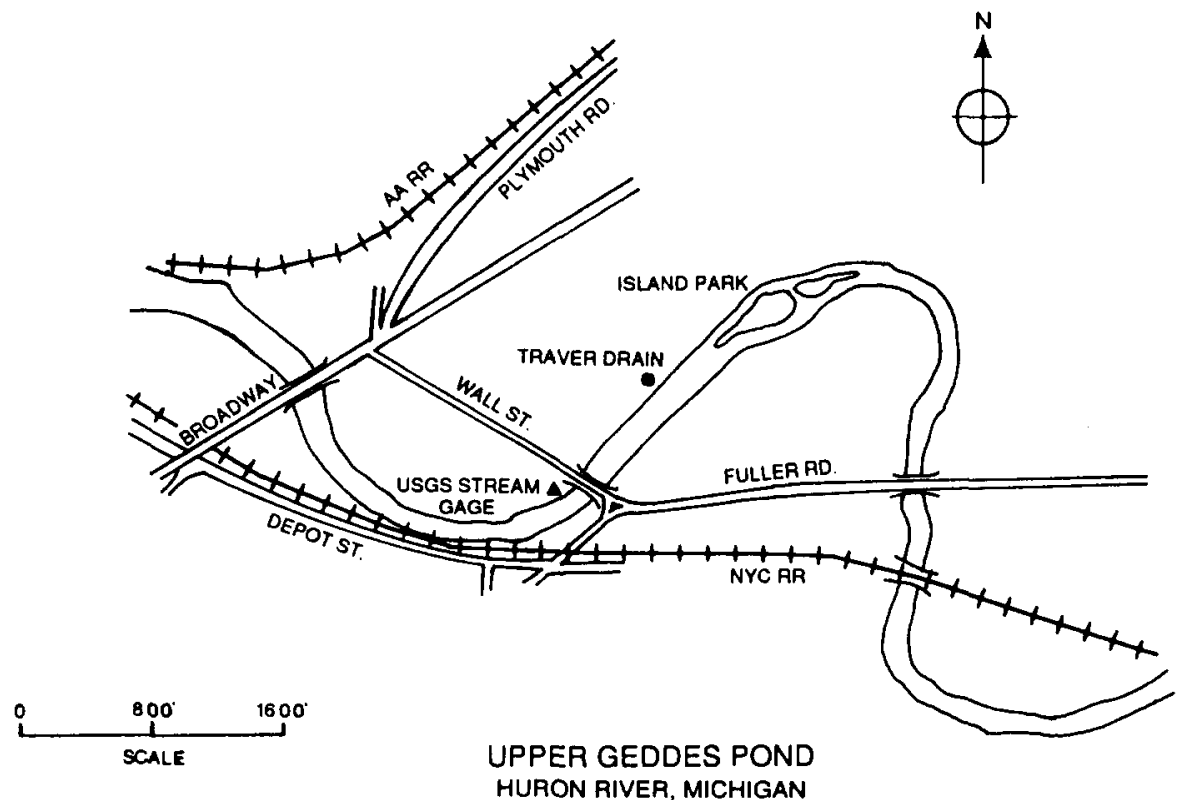

Fig. 2. Location of Traver drain.

lated from the creek mouth sediments. Lighting and temperature was as in the dry weather simulation studies. For example, there was one model each for FC and FS, and for the combination of FC + FS. Sampling was carried out as for the dry weather models.

Predation effects were also determined using cycloheximide-treated models and by comparing FC and FS survivals in these models to survivals in the untreated (natural creek water and sediments) and seeded models. Replicate models containing creek water and sediment were treated with $2 \mathrm{~g}$ cycloheximide $/ 100 \mathrm{~g}$ wet sediment in order to eliminate eukaryotic predators. Microscopic examination of the treated sediments verified the success of the treatment and no protozoa were observed. Treated and untreated models were run concurrently (12-13 days) and sampled for FC, FS, and physico-chemical measurements as for the other studies. A double layer technique producing plaques (clear zones) in the turbid upper layer containing the prey bacteria and sample inoculum was used to obtain predator counts. These counts were recorded as plaque forming units (PFUs) per $100 \mathrm{ml}$.

Water for the models was collected in 201 . carboys, and for bacterial analysis, in 11 . sterile Nalgene bottles. Sediments for analysis and the model were obtained with a modified sediment microbe sampler (Gannon et al., 1983) along a transect across the creek bottom at the outlet. Sediments were composited (combined) in sterile 11 . Nalgene bottles and transported immediately to the laboratory.

Bacteriological analysis of the samples followed Standard Methods (APHA, 1985) recommendations for the membrane filter recovery of fecal coliforms and fecal streptococci. Sediment samples were diluted, mixed, and then centrifuged at $2000 \mathrm{rpm}$ to sediment larger suspended solids. The supernatant was then processed as for typical water samples. Species identification and source of origin were determined for FC and FS as outlined in Microbiological Methods for Monitoring the Environment (U.S. EPA, 1978). $E$. coli were identified from typical FC colonies recovered with the $\mathrm{mFC}$ procedure. Isolates were classified as $E$. coli based upon their EC medium, IMViC, cytochrome oxidase, and motility test reactions (U.S. EPA, 1978). FC and FS isolated from sediments were used as seed in the seeded model studies. Seeds of known concentrations and compositions of indicator bacteria were added once to the model (one model for each seed) which was then run and sampled as for the dry weather model.

Water samples from the field and the models were analyzed for standard physico-chemical measurements, i.e. DO,

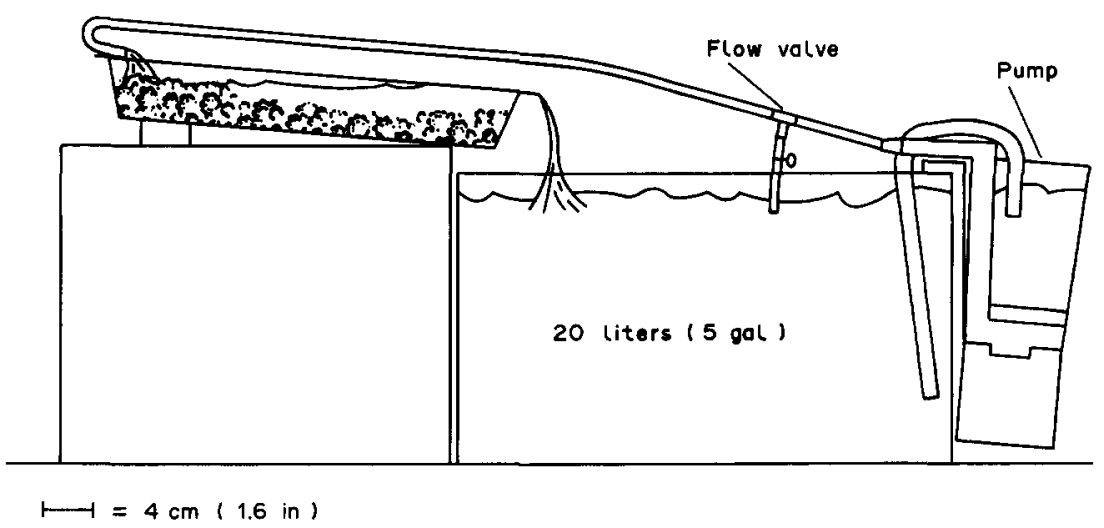

Fig. 3. Recirculating creek model. 
conductivity, $\mathrm{pH}$, temperature, according to the procedures in Standard Methods (APHA, 1985). Conductivity, expressed as the reciprocal of resistance, is a measure of the capacity of an aqueous solution to conduct an electrical current. It is dependent upon the concentrations of ions (i.e. dissolved minerals) in solution and the temperature. Conductivity was measured in order to evaluate the effect of dissolved minerals on bacterial survival. These were evaluated for their degree of correlation with bacterial survival.

Procedures for determining total solids (TS) and total volatile solids (TVS) followed APHA (1985). Sediment characterization followed the procedures of U.S. GS (1977) and Schillinger (1982). Physico-chemical measurements of $\mathrm{DO}$, conductivity, and $\mathrm{pH}$ were obtained with a YSI model 57 Oxygen meter, a YSI 33 SCT meter, and a Corning Model 125 meter, respectively.

Predator isolation and enumeration followed a modified double-layer technique (McCambridge and McMeekin, 1980). Diluted sediment samples were added to $5 \mathrm{ml}$ of tryptic soy broth $+0.7 \%$ agar containing a prey culture $\left(10^{10}\right.$ cells $/ \mathrm{ml}$ of either FC or FS). This was mixed and poured into $100 \mathrm{~mm}$ plates containing $10 \mathrm{ml}$ of tryptic soy agar $(1.5 \% \mathrm{wt} / \mathrm{vol})$. The plates were incubated at room temperature $\left(21-23^{\circ} \mathrm{C}\right)$ for $2-3$ days. Predators were counted as plaque forming units (PFUs) $/ 100 \mathrm{ml}$ and were identified by microscopic examination of the plaques. Protozoan isolation and identification followed Biological Stain Commission methods (Clark, 1973; Edmonson, 1959).

A recirculating laboratory stream model was devised to simulate dry weather creek conditions (see Fig. 3) A glass tray $345 \mathrm{~mm}$ long $\times 240 \mathrm{~mm}$ wide $\times 50 \mathrm{~mm}$ deep (13.5 $\times 9.5 \times 2$ in.) containing a $1: 1: 1$ proportion of rocks, sediments, and water (total volume $=31$.) from the creek was used to simulate the creek bottom. The area of creek bottom sampled to the area of the sediments in the model is $1000: 1$. Creek water from a 201 . (5 gal.) reservoir is pumped through the tray which overflows to the reservoir. The flow through the tray is proportional to the creek mean dry weather flow (about $0.2 \mathrm{cfs}$ ) on an area basis (1000:1). The reservoir is a standard all-glass, $5 \mathrm{gal}$. aquarium. The pump used is an electromagnetically driven aquarium power filter (Marineland). Tygon tubing with an in-line T-connector and clamp valve added to regulate the flow is used to circulate the water from the pump to the tray.

Data were analyzed with the Michigan Interactive Data Analysis System (MIDAS) computer program for data manipulation and statistical analysis (Fox and Guire, 1976). Basic analyses were performed to determine the data's conformity to a normal distribution. Univariate one-way analysis of variance (ANOVA) determined significant variable mean (e.g. FC, FS) differences for the different treatments and the equality of treatment mean variances. The effect of treatment on bacterial survival and on physicochemical factors was evaluated by profile analysis (Morrison, 1976). This analysis compares graphs (profiles) of group (e.g. FC, FS, DO, etc.) data and determines whether the profiles are parallel (similar), if day to day group responses are similar, and if mean treatment values are different.

A correlation analysis tested the degree of association among the different variables. The quantity of data did not permit the appropriate use of regression analysis.

\section{RESULTS}

Creek field studies determined that FC and FS in the sediments remained stable for up to 6 days (the maximum interstorm dry period) at $10^{4}-10^{5}$ counts $/ 100 \mathrm{ml}$ in 6 replicate studies ( 3 in fall 1987 and 3 in fall 1988; Figs 4 and 5). The FC and FS water column counts for this period were $<400$ and $<700 / 100 \mathrm{ml}$, respectively. Note in all figures (graphs), the upper error bars are asymmetrical compared to lower because of the log scale used.

Uncovered and covered models containing otherwise untreated drain water and sediment were tested in order to determine the effects of ambient fluorescent lighting on bacterial survival in sediments (11 replicates, 6 uncovered and 5 covered). FC, FS, DO, $\mathrm{pH}$, and temperature exhibited equivalent (parallel) mean profiles and treatment responses (values). Hence, the data were pooled and thereafter only uncovered models were used.

Three replicates were tested during October and December of 1988. Profile analysis of the 1987 and 1988 models revealed that the FC and FS profiles were parallel with minor physico-chemical differences, e.g. pH was more variable in 1988 than in 1987 but the ranges were small, 0.3 vs 0.2 , respectively. Thus, the 1987 and 1988 model data were pooled for comparison analysis with the treated model data.

Two replicates of models containing autoclaved creek water and sediment into which were seeded either FC and FS, FC, or FS previously isolated from the creek, were studied. This treatment eliminated both predators and competitors/antagonists. FC and

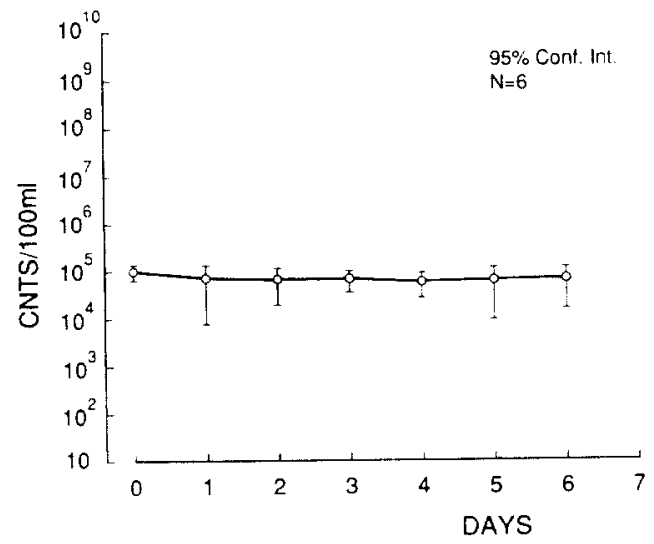

Fig. 4. Mean FC Traver Creek sediment, 1987-1988.

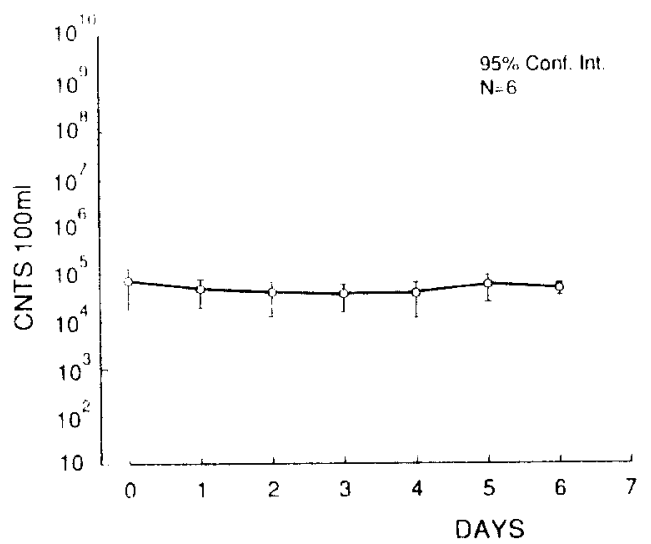

Fig. 5. Mean FS Traver Creek sediment, 1987-1988 


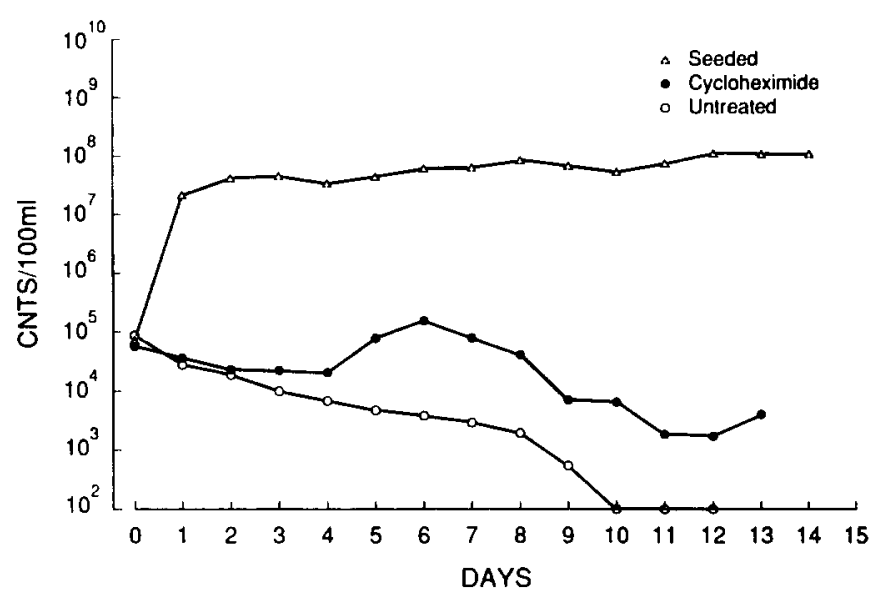

Fig. 6. Mean FC: untreated (1987-1988), cycloheximide, and seeded models.

FS increased $10^{3}-10^{5}(3-5$ logs $)$ over the initial seed concentrations. FC alone or with FS survived at $10^{8}-10^{9}$. FS alone survived at $10^{7}$ and with $\mathrm{FC}$ at $10^{8}$. FC and FS stabilized at levels that were 3-4 logs greater than in the creek which in turn were 1-2 logs greater than in the untreated models (1987-1988).

Three replicate studies were conducted where models were treated with cycloheximide in order to eliminate protozoan (and fungal) predators. Microscopic examination of the sediments confirmed the efficacy of the treatment. Possible effects of cycloheximide on the bacteria were determined in FC and FS cultures with and without cycloheximide at concentrations comparable to the model. Cycloheximidetreated and untreated cultures exhibited equivalent growth rates and equilibrium densities. This agrees with Whiffen (1948) who reported that none of the 12 bacterial species tested (including $E$. coli and $S$. faecalis) were inhibited by $1 \mathrm{mg}$ cycloheximide $/ \mathrm{ml}$. McCambridge and McMeekin $(1979,1980)$ reported similar results in their studies. Without predators, FC survived at levels comparable to the creek $\left(10^{5} / 100 \mathrm{ml}\right)$ and 2 logs higher than in the untreated models (Fig. 6). FS survived at $10^{4}$ counts $/ 100 \mathrm{ml}$ of
1 log less than the creek but 1 log higher than in the untreated models (Fig. 7). Based upon profile analysis, all factors except FS were comparable for cycloheximide-treated models and the creek.

Predator populations in the untreated models (1988) were measured with a bilayer recovery technique developed from that described for use with water samples. Plaques (clear zones) developing in the turbid semi-solid overlay indicate destruction of the bacteria. Microscopic examination of the plaques revealed that the predators were ciliated protozoa; no fungi, metazoa, or viruses (i.e. plaques with no identifiable cause) were observed. In 2 replicates, FC declined for the first 3 days while predators increased slightly. In the third case, predators did not increase as FC levels fell. As the FC stabilized, the predators declined and then stabilized at lower levels (Fig. 8). As FS declined (days 1-3), predators remained stable at initial levels, then as FS stabilized the predators declined slightly or showed a slight increase then decrease, i.e. predators did not respond very much to FS changes (Fig. 9). FC and FS have an $r=0.6732(P=0.0004)$, and an $r^{2}=0.4532$. FC and FC predators had an $r=0.6112(P=0.0004)$,

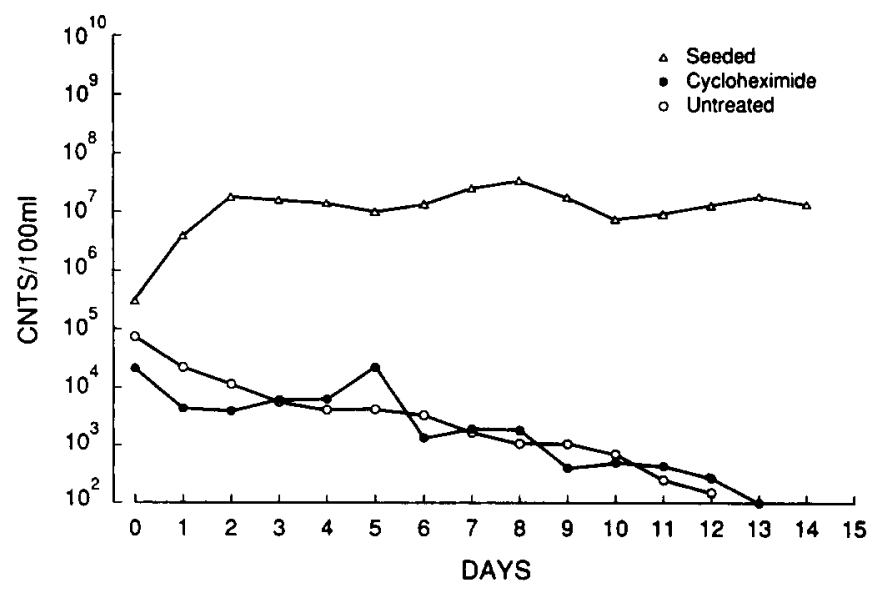

Fig. 7. Mean FS: untreated (1987-1988), cycloheximide, and seeded models. 


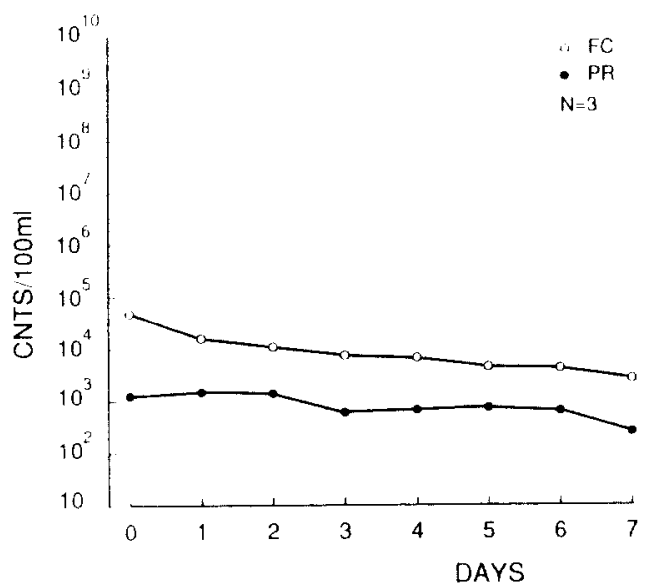

Fig. 8. Means FC and predators.

$r^{2}=0.3736$. FS and predators were not significantly correlated.

Profile analysis of the creek and the untreated models (1987-1988) during equilibrium indicated that FC and FS population trends and physico-chemical trends were parallel. All factors except DO exhibited differences in magnitude. In terms of FC and FS, this reflected the 1-2 log difference between the creek and the untreated models concentrations.

The effects of the various treatments on specific biotic components are summarized in Table 1. Figures 6 and 7 compare the bacterial profiles by treatment. Untreated model bacterial densities were 2 logs less than in the creek. Cycloheximide-treatment increased FC survival by 1 log. Autoclaved models seeded with FC and FS exhibited densities which were greater by 6 and 4 logs, respectively, than untreated model densities

The difference between cycloheximide-treated and control survivals divided by the total population

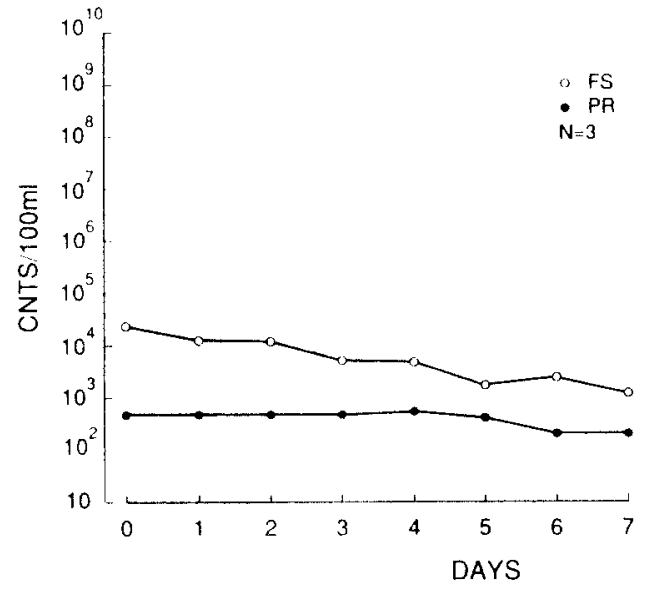

Fig. 9. Means FS and predators.

increase yields an estimated predation effect of $33 \%$. Similarly, the difference between autoclaved and seeded and cycloheximide-treated survivals yields an estimated competition/antagonism effect of $66 \%$. When the same calculations are performed for FS as for FC, the predation and competition/antagonism effects are estimated at 25 and $75 \%$, respectively.

Sediments from the 1988 studies $(n=4)$ were analyzed for TS, TVS, and particle type (Table 2). The solids analysis indicated that the organic matter content ranged from 1.1 to $2.5 \%$. Particle analysis indicated that the sediments were $93 \%$ sands and $7 \%$ silts and clays.

\section{DISCUSSION}

The data presented in this study are unique because of the sampling protocol followed and the stream model employed. Sampling protocol differed between this and other studies in terms of sampling frequency

Table 1. Summary of treatment effects

\begin{tabular}{|c|c|c|c|}
\hline \multirow[b]{2}{*}{ Treatment } & \multicolumn{2}{|c|}{ Bacterial effects } & \multirow[b]{2}{*}{ Biological effects } \\
\hline & $\mathrm{FC}^{*}$ & FS* $^{*}$ & \\
\hline $\begin{array}{l}\text { Untreated (control) } \\
\text { Creek } \\
\text { Cycloheximide treated } \\
\text { Autoclaves (seeded) }\end{array}$ & $\begin{array}{l}10^{3} \\
10^{5} \\
10^{5} \\
10^{9}\end{array}$ & $\begin{array}{l}10^{3} \\
10^{5} \\
10^{4} \\
10^{7}\end{array}$ & $\begin{array}{l}\text { Predators, competitors and antagonists present } \\
\text { Predators, competitors and antagonists present } \\
\text { Predators eliminated } \\
\text { Predators, competitors and antagonists eliminatec }\end{array}$ \\
\hline
\end{tabular}

${ }^{*} \log _{10} / 100 \mathrm{ml}$.

Table 2. Sediment characteristics*

\begin{tabular}{lccccccc}
\hline & & & \multicolumn{5}{c}{ Percentage composition } \\
\cline { 3 - 8 } Sample date & TS (g) & TVS (g) & $\begin{array}{c}\text { Organic } \\
\text { matter } \dagger\end{array}$ & $\begin{array}{c}\text { Coarse } \\
\text { sand } \ddagger\end{array}$ & $\begin{array}{c}\text { Medium } \\
\text { sand }\end{array}$ & $\begin{array}{c}\text { Fine } \\
\text { sand }\end{array}$ & $\begin{array}{c}\text { Silt } / \\
\text { clay }\end{array}$ \\
\hline $\begin{array}{c}6 / 6 / 1988 \\
(n=2)\end{array}$ & 29.5 & 0.74 & 2.5 & 62.0 & 19.3 & 9.0 & 9.7 \\
$\begin{array}{c}7 / 14 / 1988 \\
(n=4)\end{array}$ & 52.2 & 1.09 & 2.1 & 53.3 & 27.2 & 10.7 & 8.8 \\
$\begin{array}{c}10 / 5 / 1988 \\
(n=2)\end{array}$ & 50.0 & 0.62 & 1.23 & 50.8 & 34.6 & 8.8 & 5.9 \\
$\begin{array}{c}12 / 6 / 1988 \\
(n=4)\end{array}$ & 50.2 & 0.58 & 1.16 & 22.6 & 62.0 & 12.1 & 3.3 \\
\hline
\end{tabular}

*Values reported as means. + Grand mean $=1.7 \%$, range $=1.16-2.5$; percentage loss on combustion. $¥$ Total mean sand: silt/clay $(\%)=93: 7$. 
and recovery methods. In this study, both creek and models were sampled daily-the former for 6 days and the latter for up to 15 days. Most other studies reported sporadic, single, bimonthly, monthy, or otherwise irregular sampling of sediments (e.g. LaBelle et al., 1980; O'Malley et al., 1982; Erkenbrecher, 1981; Sayler et al., 1975; Gannon et al., 1983; Matson et al., 1978; Grimes, 1975, 1980; Struck, 1988; Van Donsel and Geldreich, 1971). For the determination of long-term bacterial survival in the field and for modeling that survival under laboratory conditions, this procedural difference is critical. In the creek studies, daily interstorm dry period sampling permitted the determination of long-term FC and FS survival in sediments in the absence of continual or sporadic bacterial supplementation during the sampling period, i.e. there were no allochthonous bacterial sources from runoff. Point sources were eliminated by the selection of Traver Creek, which has no known point sources of pollution. Thus, the FC and FS sediment populations monitored during dry weather were derived from a single seeding by the previous storm event. No additional bacterial loadings occurred until the next storm event. Additionally, there was no evidence for bacterial augmentation from animal feces since feces were never observed in the shallow creek and no spikes in population densities were found. In the field studies cited, the non-daily sampling frequency did not ensure that the same bacterial populations were monitored and sampling sites were not selected in order to eliminate continuous or sporadic point source additions.

LaLiberti and Grimes (1982), Hendricks and Morrison (1967), Struck (1988), Hood and Ness (1982), Van Donsel and Geldreich (1971), Gerba and McLeod (1976), Geldreich (1970), and Burton et al. (1987) reported somewhat similar results to those reported here, although their modeling methods are different. LaLiberti and Grimes (1982) used dialysis tubing bags containing sediments and water which were maintained in situ. Hendricks and Morrison (1967) also used an in situ dialysis-sac model. Struck (1988), Hood and Ness (1982), and Gerba and McLeod (1976) used "bottle" or "jar" models. Van Dosel and Geldreich (1971) presumably used the "bottle" model for their stored mud samples. Burton et al. (1987) used a model that was similar to the one used in the present study except that the flow simulated a retention basin with a 7 day retention time.

The possibility that indicator bacteria are capable of multiplying in the aquatic sediments has been suggested numerous times in the literature. This is based upon the general finding that indicator bacterial densities in sediments are 2-3 logs greater than in overlying waters. However, no specific studies were conducted to test this hypothesis. The present study attempted to answer this question by field and laboratory studies. The field study protocol ensured that the same FC and FS populations were monitored throughout a given interstorm period, i.e. no additional bacterial supplementation from stormwater runoff, seepage, animal feces, illegal connections or point sources occurred during a given study. The laboratory studies determined the effect of biotic and abiotic factors, and demonstrated reproductive capability in low nutrient, sterile sediments. Considered together, these results suggest that indicator bacteria (particularly FC) may indeed be multiplying in aquatic sediments, since the populations maintained themselves at high densities in the presence of constant predation and competition/antagonism effects and without significant external supplementation.

Many researchers have investigated the effects of predation, competition, and antagonism (i.e. biotic factors) on bacterial populations in soils, activated sludges, sewage, fresh, and estuarine-marine waters (Coler and Gunner, 1969; Habte and Alexander, 1978; Tate, 1978; Danso and Alexander, 1975; Curds et al., 1968; Curds and Fey, 1969; Curds, 1973; Mallory et al., 1983; Enzinger and Cooper, 1976; McCambridge and McMeekin, 1979, 1980; Roper and Marshall, 1978; Barna and Weis, 1973). All these studies indicate that protozoan predation is a major biotic factor limiting bacterial survival in soils, sludges, sewage, fresh, and estuarine waters. Bacterial predation/parasitism constitutes a lesser factor because the bacterial agents are themselves subject to protozoan predation, which limits their predatory activity. Predation is density-dependent and, in natural systems, large numbers of prey will normally only be reduced to a certain minimum (equilibrium) density, but not eliminated. At equilibrium, the predation rate is balanced by the "replacement" rate (i.e. reproduction, import) of the prey. The rate of predation is affected by initial predator densities, with higher densities resulting in higher predation rates. Competition and antagonism are less important than predation, both protozoan and bacterial, in limiting bacterial populations under the conditions studied. Cell-free toxins are not significant factors.

In this study, protozoan predation was also found to be a major factor affecting FC and FS survivals in storm drain sediments. Bacterial predators/parasites were not significant factors since bacteria were not identified as plaque-forming agents. Approximately stable predator and prey densities were established in the models after an initial 2 day period of predator increase (for FC predators) concurrent with prey declines. That predation on FC was greater than on FS is consistent with the observations by Barna and Weis (1973) and Coler and Gunner (1969). They found that Gram negative bacteria are the preferred prey of soil and aquatic protozoa. Since Gram negative bacteria are the most common type of soil and aquatic bacteria, one would expect there to be naturally occurring populations of appropriate protozoan predators in aquatic sediments. Fecal streptococci, a Gram positive bacterial group, would not be as readily preyed upon as would be FC by such preda- 
tors, as was observed. Equilibrium bacterial densities were maintained in the creek, as indicated by stable FC and FS densities in the sediment during dry weather. Site selection, sampling period, and daily site inspection ensured that these densities were not maintained by allochtonous sources. This suggests that bacterial reproduction was replacing cells lost by predation, at least for FC. Fecal streptococci densities may be maintained differently (see below).

Competition and antagonism appeared to be more important in this study than in other's studies. These factors comprised $66-75 \%$ of the biotic effect on FC and FS survivals, with the remaining $25-33 \%$ effect due to predation. It is possible that these effects are over-estimated for competition and antagonism and under-estimated for predation. Competition/ antagonism effects were deduced from cycloheximidetreated model data compared to untreated and autoclaved-seeded model data. Cycloheximide eliminated protozoan predators which may have allowed bacterial predators/parasites to increase in number and activity thereby suppressing the FC and FS population increases observed. This would have resulted in an over-estimation of competition/antagonism effects and a corresponding under-estimation of the predation effect. Although bacterial predators were not identified from plaques, their possible effects could not be identified by the treatment procedures used. Statistical analysis of FC densities and protozoan numbers from plaques resulted in an overall significant coefficient of determination of 0.37 (i.e. $37 \%$ predation effect) while the coefficient for FS and predators was 0.25 , but not significant. The $37 \%$ effect is probably conservative since it is based on predator counts obtained by a conservative recovery technique (Enzinger and Cooper, 1976). However, it is in good agreement with the $33 \%$ predation effect inferred from treatment effect differences.

FC and FS densities were stable in the creek sediment during dry weather. It is suggested here that since the creek did not receive external bacterial supplementation between storm events and FC are subject to at least a $33-37 \%$ predation effect, the observed stable FC densities are probably due to FC multiplication at a rate equal to the rate of predation. For FS populations, there may be little multiplication occurring to maintain densities (compared to FC) but this is compensated by the lower predation effect of $25 \%$ and the presence of preferred prey (FC). Stable bacterial survivals in untreated sediments indicated that nutrients should not be limiting for about 7 days, which is longer than the mean dry weather period. Thus, competition may not be a critical factor under field conditions (see also sewage and estuarine studies). Fecal coliform populations were more responsive to the various model treatments than were the FS. The FS densities did not increase comparably to the FC when treated with cycloheximide or when seeded into autoclaved models, indicating less reproductive capability under predator-free and even predatorand competitor/antagonist-free conditions.

Different reproductive capabilities for FC and FS under natural and experimental conditions have been reported previously (Kittrell and Furfari, 1963; Scarce et al., 1964; Hanes and Fragala, 1967; Savage and Hanes, 1971; Shuval et al., 1973). These studies agree with the present study which found that FC exhibits greater reproductive ability than FS, under simulated field conditions. Some of these studies also demonstrate the ability of $\mathrm{TC}$ and FC to multiply under field conditions. Other studies which demonstrated selective protozoan predation on Gram negative bacteria, including $E$. coli, agree with this study which found greater predation on FC than on FS. These results support the interpretation presented here, that stable FC populations in creek sediments are maintained by a dynamic equilibrium between bacterial multiplication and protozoan predation. Stable FS populations are maintained by a "passive" equilibrium between extended persistence (with perhaps a minimal multiplication) and relatively little protozoan predation.

Under typical field conditions, competition and antagonism effects may not be as important to bacterial survivals as was deduced from the model studies. Model bacterial populations established equilibrium levels which persisted for up to 7 days, as observed in the field. After this stable period (days 9-10 of the study), the counts gradually declined, a phenomenon not observed in the field. This decline probably reflects the exhaustion of available nutrients and perhaps the accumulation of inhibiting metabolites in the model, as would be expected in a closed system containing relatively little organic matter $(1.2-2.5 \%)$. The creek, as an open system, would have continuous nutrient supplementation and metabolites would be washed-out. Even so, the equilibrium state was maintained for a longer time ( 7 days) in the models than in the creek (5-6 days). Since the creek, unlike the model, is not nutrient-limited, competition probably is not as important a survival factor in the creek as in the models. Although antagonism effects could not be isolated by treatment methods, no antagonists were identified from plaques and the literature also indicates that bacterial antagonists in aquatic systems are of minor importance. Hence, antagonism probably is not a major survival factor in the creek or the models.

The models at equilibrium are comparable to the creek, both in terms of FC and FS survival trends and in regard to physico-chemical changes over time. The two systems differ in the magnitudes of the various factors and in day-to-day changes in bacterial densities. However, only the differences in magnitude of the bacterial populations are important in the context of this study. Since the model bacterial densities are consistently 2 logs less than in the creek, correcting these densities by 2 logs yields the equivalent creek densities. 
The results from the model at equilibrium can be extrapolated to the creek. Abiotic factors were not as important as biotic factors for bacterial survival in both systems. This is valid during warm weather (late spring through early fall) when these studies were conducted. Undoubtedly, temperature and perhaps conductivity and $\mathrm{pH}$ would have become more important during the late fall through early spring months. During the warm weather months, these factors were relatively stable in the creek and in the models. Biotic factors were major determinants of bacterial survival in the models. The reported predation effects are conservative estimates, while competition/antagonism effects are probably overestimated. Since the creek is not nutrient-limited, as is the model, competition is probably not as signifcant an effect in the creek. Antagonism is a minor factor.

Given that the untreated models are flowing simulations containing minimally disturbed creek materials and that the indicator bacteria and physicochemical factors respond similarly through time in the models and the creek, it is reasonable to assume that the same biotic and abiotic effects are operative in both systems. The difference between the models and the creek is one of degree. It is possible that predation assumes a greater role than competition and antagonism in regulating the survival of indicator bacteria in creek sediments.

\section{CONCLUSIONS}

(1) Storm drain sediments function as reservoirs of high concentrations of FC and FS bacteria during warm, dry weather periods of up to 6 days.

(2) FC exhibit an ability to multiply in drain sediment which has a low organic content and reduced predator populations while FS do not.

(3) Native microfloral competition/antagonism (including bacterial predation) and protozoan predation are major biotic factors influencing FC and FS survivals. Competition/antagonism exerts a two to three times greater effect on fecal bacterial survival than does predation under simulated conditions. The relative importance of these factors under field conditions is still uncertain.

(4) Abiotic factors appear to have minimal affects on FC and FS survivals during warm, dry weather periods both in the field and in the models.

\section{REFERENCES}

APHA (1985) Standard Methods for the Examination of Water and Wastewater, 16th edition. American Public Health Association, New York.

Barna I. and Weis D. S. (1973) The utilization of bacteria as food for Paramecium bursariae. Trans. Am. Microsc. Soc. 92, 434-440.

Benzie W. J. and Courchaine R. J. (1966) Discharges from separate storm sewers and combined sewers. J. Wat. Pollut. Control Fed. 38, 410-421.
Bonde G. J. (1967) Pollution of a marine environment. J. Wat. Pollut. Control Fed. 39, R45-R63.

Burm R. J. and Vaughan R. D. (1966) Bacteriological comparison between combined and separate sewer discharges in southeastern Michigan. J. Wat. Pollut. Control Fed. 38, 400-409.

Burton G. A. Jr, Gunnison D. and Lanza G. R. (1987) Survival of pathogenic bacteria in various freshwater sediments. Appl. envir. Microbiol. 53, 633-638.

Clark G. (Ed.) (1973) Staining Procedures Used by the Biological Stain Commission, 3rd edition. Biological Stain Commission, Williams \& Wilkins, Baltimore, Md.

Coler R. A. and Gunner H. B. (1969) Microbial populations as determinants in protozoan succession. Wat. Res. 3, 149-156.

Curds C. R. (1973) The role of protozoa in the activatedsludge process. Am. Zool. 13, 161-169.

Curds C. R. and Fey G. J. (1969) The effect of ciliated protozoa on the fate of Escherichia coli in the activatedsludge process. Wat. Res. 3, 853-867.

Curds C. R., Cockburn A. and Vandyke J. M. (1968) An experimental study of the role of ciliated protozoa in the activated-sludge process. J. Wat. Pollut. Control Fed. 67, 312-329.

Danso S. K. and Alexander M. (1975) Regulation of predation by prey density: the protozoan-Rhizobium relationship. Appl. Microbiol. 29, 515-521.

Department of Environmental and Industrial Health (1986) Huron River Water Quality Study. Water Quality Program Faculty and Students, Dept Envir. Ind. Hlth, School of Public Health, The University of Michigan, Ann Arbor, Mich.

Edmondson W. T. (Ed.) (1959) Ward and Whipple Freshwater Biology, 2nd edition. Wiley, New York.

ENCOTEC (1982) Evaluation of Urban Stormwater Runoff and Management Practices for Controlling Urban Stormwater Runoff. Environmental Control Technology Corporation, Ann Arbor, Mich.

Enzinger R. M. and Cooper R. C. (1976) Role of bacteria and protozoa in the removal of Escherichia coli from estuarine waters. Appl. envir. Microbiol. 31, 758-763.

Erkenbrecher C. W. Jr (1981) Sediment bacteria indicators in an urban shellfishing sub-estuary of the lower Chesapeake Bay. Appl. envir. Microbiol. 42, 484-492.

Fox D. J. and Guire K. E. (1976) Documentation for $M I D A S$, 3rd edition. Statistical Research Laboratory, The University of Michigan, Ann Arbor, Mich.

Gannon J. J., Busse M. K. and Schillinger J. E. (1983) Fecal coliform disappearance in a river impoundment. Wat. Res. 17, 1595-1601.

Gary H. L. and Adams J. C. (1985) Indicator bacteria in water and stream sediments near Snowy Range in southern Wyoming. Wat. Air Soil Pollut. 25, 133-144.

Geldreich E. E. (1970) Applying bacteriological parameters to recreational water quality. J. Am. Wat. Wks Ass. 62, 113-120.

Geldreich E. E., Best L. C., Kenner B. A. and Van Donsel D. J. (1968) The bacteriological aspects of stormwater pollution. J. Nat. Pollut. Control Fed. 40, 1816-1872.

Gerba C. P. and McLeod J. S. (1976) Effect of sediments on the survival of Escherichia coli in marine waters. Appl. envir. Microbiol. 32, 114-120.

Goyal S. M., Gerba C. P. and Melnick J. L. (1977) Occurrence and distribution of bacterial indicators and pathogens in canal communities along the Texas coast. Appl. envir. Microbiol. 34, 139-149.

Goyal S. M., Gerba C. P. and Melnick J. L. (1979). Transferable drug resistance in bacteria of coastal canal water and sediment. Wat. Res. 13, 349-356.

Grimes D. J. (1975) Release of sediment-bound fecal coliforms by dredging. Appl. Microbiol. 29, 109-111.

Grimes D. J. (1980) Bacteriological water quality effects of hydraulically dredging contaminated upper Mississippi 
River bottom sediments. Appl. envir. Microbiol. 39, 782-789.

Habte M. and Alexander M. (1978) Protozoan density and the coexistence of protozoan predators and bacterial prey. Ecology 59, 140-146.

Hanes N. B. and Fragala R. (1967) Effect of seawater concentration on survival of indicator bacteria. $J$. Wat. Pollut. Control Fed. 39, 97-104.

Hendricks C. W. (1971) Increased recovery rate of Salmonella from stream bottom sediments versus surface waters. Appl. envir. Microbiol. 21, 379-380.

Hendricks C. W. and Morrison S. M. (1967) Multiplication and growth of selected enteric bacteria in clear mountain stream water. Wat. Res. 1, 567-576.

Hood M. A. and Ness G. E. (1982) Survival of Vibrio cholerae and Escherichia coli in estuarine waters and sediments. Appl. envir. Microbiol. 43, 578-584.

Kittrell F. W. and Furfari S. A. (1963). Observations of coliform bacteria in streams. J. Wat. Pollut. Control Fed. $35,1361-1385$

LaBelle R. L., Gerba C. P., Goyal S. M., Melnick J. P., Cech I. and Bogdan G. F. (1980) Relationships between environmental factors, bacterial indicators, and the occurrence of enteric viruses in estuarine sediments. Appl. envir. Microbiol. 39, 588-596.

LaLiberti P. and Grimes D. J. (1982) Survival of E. col in lake bottom sediments. Appl. envir. Microbiol. 43, 623-628.

Mallory L. M., Yuk C., Liang L. and Alexander M. (1983) Alternative prey: a mechanism for elimination of bacterial species by protozoa. Appl. envir. Microbiol. 46, 1073-1079

Matson E. A., Horner S. G. and Buck J. D. (1978) Pollution indicators and other microorganisms in river sediments. J. Wat. Pollut. Control Fed. 50, 13-19.

McCambridge J. and McMeekin T. A. (1979) Protozoan predation of Escherichia coli in estuarine waters. Wat. Res. 13, 659-663.

McCambridge J. and McMeekin T. A. (1980) Relative effects of bacterial and protozoan predators on survival of Escherichia coli in estuarine water samples. Appl envir Microbiol. 40, 907-911.

McDonald A.. Kay D. and Jenkins A. (1982) Generation of fecal and total coliform surges by stream fow manipu lation in the absence of normal hydrogeologic stimuli. Appl. envir. Microbiol. 44, 292-300.

Morrison D. F. (1976) Multivariate Statistical Methods, 2nd edition. McGraw-Hill, New York.

O'Malley M. L., Lear D. W., Adams W. N., Gaines J., Sawyer T. K. and Lewis E. J. (1982) Microbial contamination of continental shelf sediments by wastewater. J. Wat. Pollut. Control Fed. 54, $1311-1317$.

Qureshi A. A. and Dutka B. J. (1979) Microbiological studies on the quality of urban stormwater runoff in southern Ontario, Canada. Wat. Res. 13, 977-985.

Rittenberg S. C., Mittwer T. and Ivler O. (1958) Coliform bacteria in sediments around three marine sewage outfalls. Limnol. Oceanogr. 3, 101-108.
Roper M. M. and Marshall K. C. (1978) Effects of a clay mineral on microbial predation and parasitism of Escherichia coli. Microb. Ecol. 4, 279-289.

Savage H. P. and Hanes N. B. (1971) Toxicity of seawater to coliformbacteria.J.Wat.Pollut.ControlFed.43,854-861.

Savage W. G. (1905) Bacteriological examination of tidal mud as an index of pollution of the river. J. Hyg., Camb. $5,146-174$

Sayler G. S., Nelson J. D. Jr, Justice A. and Colwell R. R. (1975) Distribution and significance of fecal indicator organisms in the Upper Chesapeake Bay. Appl. envir. Microbiol. 30, 625-638.

Scarce L. E., Rubenstein S. H. and Megregian S. (1964) Survival of indicator bacteria in receiving waters under various conditions. Great Lakes Res. Div. (The University of Michigan), Publ. No. 11, pp. 130-139.

Schillinger J, E. (1982) Bacterial adsorption to suspended particles in urban stormwater. Dissertation University of Michigan

Schillinger J. E. and Gannon J. J. (1985) Bacterial adsorption and suspended particles in urban stormwater. $J$. Wat. Pollut. Control Fed. 57, 384-389.

Shuval H. I., Cohen J. and Kolodney R. (1973) Regrowth of coliforms and fecal coliforms in chlorinated wastewater effluent. Wat. Res. 7, 537-546.

Struck P. H. (1988) The relationship between sediment and fecal coliform levels in a Puget Sound Estuary. J. envir. Hlth 50, $403-407$.

Tate R. L. III (1978) Cultural and environmental factors affecting the longevity of Escherichia coli in histosols. Appl. envir. Microbiol. 35, 925-929.

U.S. EPA (1978) Microbiological Methods for Monitoring the Environment: Water and Wastes. Envir. Monitor. and Supp. Lab., Off. Res and Dev., U.S. Envir. Protect. Agen., Cincinnati, Ohio.

U.S. GS (1977) National Handbook of Recommended Methods for Water Data Acquisition. U.S. Geological Survey, Dept of the Interior. Reston, Va.

Van Donsel D. J. and Geldreich E. E. (1971) Relationship of salmonellae to fecal coliforms in bottom sediments. Wat. Res. 5, 1079-1087.

Varness K. J., Pacha R. E. and Lapen R. F. (1978) Effects of dispersed recreational activities on the microbiological quality of forest surface water. Appl. envir. Microbiol. 36, 95-104.

Washtenaw County Drainage Board and SEMCOG (1981) Controlling Urban Stormwater Runoff in Washtenaw County. Washtenaw County Drainage Board and the Southeast Michigan Council of Governments, Detroit, Mich.

Weibel S. R., Anderson R. J. and Woodward R. L. (1964) Urban land runoff as a factor in stream pollution. $J, W a t$. Pollut. Control Fed. 36, 914-924.

Weiss C. M. (1951) Adsorption of E. coli on river and estuarine silts. Swge Indust. Wastes 23, 227-237.

Whiffen A. J. (1948) The production, assay, and antibiotic activity of actidione, an antibiotic from Streptomyces griseus. J. Bact. 56, 283-291. 